\title{
Effect of moisture stress on seed germination and early seedling growth of pulse crops
}

\author{
Saeed Ahmed ${ }^{1}$, Zafar Ullah², Zia ul Haq ${ }^{2}$, Muhammad Raza \\ Siddiqui ${ }^{2}$ and Sohail Latif ${ }^{3}$ \\ 1. Department of Sindh Agriculture University Tandojam-Pakistan \\ 2. Department of Balochistan Agricultue College Quetta-Pakistan \\ 3. Research Farm Crops, Boldmas District Kotli, Agriculture Department of Azad Jammu and Kashmir-Pakistan \\ *Corresponding author's email: zumalghani@gmail.com
}

Citation

Saeed Ahmed, Zafar Ullah, Zia ul Haq, Muhammad Raza Siddiqui and Sohail Latif. Effect of moisture stress on seed germination and early seedling growth of pulse crops. Pure and Applied Biology. Vol. 7, Issue 2, pp775-782. http://dx.doi.org/10.19045/bspab.2018.70096

\begin{tabular}{|c|c|c|c|}
\hline Received: 30/03/2018 & Revised: 29/05/2018 & Accepted: 19/06/2018 & Online First: $28 / 06 / 2018$ \\
\hline
\end{tabular}

\section{Abstract}

In vitro research was conducted to determine the influence of moisture stress on germination of pulse crops in Agronomy Department, Sindh Agriculture University, Tandojam, during 2014. Four pulse crops viz: Mung bean, field pea, lentil and cow pea were tested for germination traits under three moisture stress conditions. All the crops were kept at room temperature and in germinator at $30^{\circ} \mathrm{C}$. The moisture stress significantly reduced germination and early growth parameters. The germination and growth parameter were recorded after 4 and 12 days, respectively. Root shoot ratio was calculated for growth parameters. The maximum seed germination $(87.33 \%)$, shoot length $(326.0 \mathrm{~mm})$, root length $(145.7 \mathrm{~mm})$ were recorded in field pea. Fresh shoot weight $(22640 \mathrm{mg})$, dry shoot weight $(2513 \mathrm{mg})$ and dry root weight (1897 mg) were recorded in cowpea. The minimum seed germination $(67.33 \%)$, fresh shoot weight $(2227 \mathrm{mg})$, fresh root weight $(1877 \mathrm{mg})$, were recorded in mungbean. Whereas minimum shoot length $(185.3 \mathrm{~mm})$ and root length $(85.00 \mathrm{~mm})$ were observed in cowpea and lentil, respectively. The maximum seed germination $(86.42 \%)$, root length $(112.3 \mathrm{~mm})$, fresh shoot weight and dry root weight were recorded under daily moisture conditions. Results reflected that daily and alternate day moisture application proved better germination and seedling growth traits while two days after moisture application showed stress as the result of poor growth of early plant traits. The best seed germination and growth traits were recorded in field pea while cow pea ranked second, lentil third and mung bean fourth.

Keywords: Cow pea; Field pea; Germination; Lentil; Moisture stress; Mung bean

\section{Introduction}

Food legumes are crops grown for their edible seeds belong to family Fabaceae. Their dehulled seeds are called pulses. After cereals, grain legumes are alternative source of proteins [1]. The major pulses are Chickpea, Field pea, Cow pea, Mung bean, Lentil, Red gram and Black gram. Lentil is relatively drought tolerant. Potential losses in yield can range between 6-54\%. Field pea is also sensitive to drought and yield losses varies from 21-54\%. Phenology of field pea shows its ability to escape drought as compare to other pulses. Abiotic stress like drought is one of the most important stress that intensely limits plant growth leading to decline in productivity [7]. At sowing inadequate soil moisture affects 
seed germination and unsynchronized seedling emergence, affecting the establishment of a stand, with negative effects on the yield $[2,3]$. Water deficit not only affects seed germination, but also increase germination time [4]. Factors negatively influencing seed germination may include sensitivity to drought stress [5], Successful crop production is dependent upon the healthy seedling establishment resulting from a critical stage of seed germination [6].

Cowpeas (Vigna spp.) are cultivated for dry seeds and as vegetables to feed the world population. Cowpeas bears highly efficient stress resistant traits against drought and can recover rapidly during vegetative growth stage by re-watering due to their efficiency in using soil water. Drought stress damaged the function of stomata, which limits water loss and the influx of $\mathrm{CO}_{2}$. Sank $\mathrm{CO}_{2}$ influx indicates a reduction in carbon fixation in the Calvin cycle and to a decrease in oxidized $\mathrm{NADP}+$ to assist as an electron acceptor in photosynthesis. As a result, electrons flow to the substitute electron acceptor, $\mathrm{O}_{2}$, synthesize superoxide radical. [8]. Drought marks every phase of plant growth and metabolism. The germination phase regulates the standard establishment and hence the final yield of the crop. Drought may marks in delayed and may reduce or stop germination. The seed germination is reduced at a small negative osmotic potential $[9,10]$. The initiation of cell elongation during germination is differentially sensitive to drought. The root system is reflected as primary sensor of drought stress and plays an important role in drought avoidance by deep penetration into soil [11].

Field pea (Pisum sativum L.) is a main frost-resistant and cool-season leguminous vegetable that is broadly cultivated all over the world. Its consist of $(25 \%)$ protein, (12\%) amino acids, sugars carbohydrate, vitamins $\mathrm{A}$ and $\mathrm{C}$, calcium and phosphorus, apart from having a slight quantity of iron. Peas being big source of proteins for human diet are valuable for vegetable purposes. Among the pulse crops, mung bean (Vigna radiata L.) has a special importance of intensive crop production due to its short growth period [12]. The crop cultivated in arid circumstance, encounters drought stress at different growth stages. In a symbiotic relationship with the soil bacteria, mung bean roots can fix atmospheric nitrogen and thus increase soil fertility [13]. Water stress disrupts several physiological processes connected with growth, development, and economic yield of a crop [14]. Water scarcity interrupts normal turgor pressure, and the loss of cell turgidity may stop cell enlargement that effects plant growth negatively [15].

The lentil (Lens culinaris L.) is an annually grain legume crop requiring low to medium rainfall and it has tolerance against water stress [16]. Lentils are a chief source of protein for people in the Mediterranean, Africa, Middle East, Southern Asia and South America. Lentil has been playing a significant role in human nutrition. Its seed is a good source of dietary protein. Lentil is commonly used in India, Southwest Asia, and the Mediterranean areas in the form of split lentil (dhal) and it is still an important source of dietary protein in these areas. Lentil contains approximately $22 \%$ protein while the lentil straw can be used as a source of organic material for soil improvement. Objectives of study were as: 1) to asses pulse crop seedlings behavior under moisture stress conditions, 2) to find out appropriate moisture interval to early seedling growth of pulse crops.

\section{Materials and methods}

In vitro study was conducted to determine the effect of moisture stress on germination and early seedling growth traits of pulse crops in the Department of Agronomy, Sindh Agriculture University, Tandojam, during 2014. The experiment was conducted in Complete Randomized Design (CRD) in three replications with two Factors i.e., pulse crops and moisture stress. Four pulse crops i.e. $\mathrm{P}_{1}$ (Mung 
bean), $\mathrm{P}_{2}$ (Field pea), $\mathrm{P}_{3}$ (Lentil) and $\mathrm{P}_{4}$ (Cow pea) and three moisture stress levels viz: $\mathrm{S}_{1}$ (Daily moisture), $\mathrm{S}_{2}$ (Alternate day moisture) and $\mathrm{S}_{3}$ (Two days after moisture). Treatment combinations were: $\mathrm{T}_{1}=\mathrm{P}_{1} \mathrm{~S}_{1}, \mathrm{~T}_{2}=\mathrm{P}_{1} \mathrm{~S}_{2}, \mathrm{~T}_{3}=\mathrm{P}_{1} \mathrm{~S}_{3}, \mathrm{~T}_{4}=\mathrm{P}_{2} \mathrm{~S}_{1}, \mathrm{~T}_{5}=\mathrm{P}_{2}$ $\mathrm{S}_{2}, \mathrm{~T}_{6}=\mathrm{P}_{2} \mathrm{~S}_{3}, \mathrm{~T}_{7}=\mathrm{P}_{3} \mathrm{~S}_{1}, \mathrm{~T}_{8}=\mathrm{P}_{3} \mathrm{~S}_{2}, \mathrm{~T}_{9}=\mathrm{P}_{3} \mathrm{~S}_{3}, \mathrm{~T}_{10}$ $=\mathrm{P}_{4} \mathrm{~S}_{1}, \mathrm{~T}_{11}=\mathrm{P}_{4} \mathrm{~S}_{2}$ and $\mathrm{T}_{12}=\mathrm{P}_{4} \mathrm{~S}_{3}$.

The increase in moisture stress significantly decline germination and related traits. All the pulse crops kept at room temperature and in germinator (Model-PL3) at $30{ }^{\circ} \mathrm{C}$. The seeds were moisturized as scheduled whenever necessary. After $48 \mathrm{hrs}$ data for seed germination was recorded. The length, fresh and dry weights of shoot and root, were recorded after 12 days.

The seed germination percentage was recorded using the following formula: Germination $(\%)=\underline{\text { Number of germinated seeds }}$ Total number of seeds sown

The shoot and root length in $\mathrm{mm}$ of all seedlings in a petri dish of each treatment was taken with the help of foot scale and then mean was calculated by using the following formula:

Shoot/Root length=

Summation of length of shoot or root of all seedlings Total number of seedlings

Shoots and roots were per treatment weighted in $\mathrm{mg}$ separately on digital electronic balance. The oven dry weight in $\mathrm{mg}$ at $50^{\circ} \mathrm{C}$ for 48 hours of roots and shoots of each treatment were recorded on digital electronic balance. The data was analyzed using M STAT C Computer Software. The mean were compared by Least Significant Difference (LSD) at 5\% probability level [17].

\section{Results and discussion \\ Percentage of seed germination}

The data for \%age of seed germination were significant affected by moisture stress, pulse crops and their interaction (Table 1). The results showed that maximum seed germination (86.42 and $85.00 \%$ ) was recorded in treatments where daily moisture and alternate day moisture application made while the minimum seed germination $(65.50 \%)$ was recorded where moisture application was made after two days. In case of crops the maximum seed germination of $87 \%$ was recorded in field pea, followed by lentil with $83 \%$ and cow pea with $78 \%$ whereas as the lower seed germination of $67 \%$ was observed in mung bean. The interaction for seed germination was non-significant. Water deficit is in adequate moisture for normal plant growth and to complete the life cycle [18]. Moisture plays vital role in early growth and yield traits of crops. Drought marks every phase of plant growth and metabolism. The germination phase is of main importance in the growth cycle of plants as it determines the standard establishment and final yield of the crop. Water stress may results in delayed and reduced seed germination or may stop germination completely [9]. The early growth traits of pulse were significantly influenced by moisture stress levels. It seems from results that seed germination percentage showed optimum growth at sufficient soil moisture level as alternate day moisture application and it is observed that crop Mung bean is very sensitive to moisture stress at seed germination stage than other pulse crops. Similar results were found as drought stress severely reduced germination and seedling stand [19].

\section{Shoot length $(\mathbf{m m})$}

The data for shoot length of pulse crops affected by different moisture stress levels, pulse crops and their interaction was significant presented in (Table 2). The results showed that maximum shoot length $(258.8 \mathrm{~mm})$ was recorded at alternate day moisture application; whereas the minimum shoot length $(200.3 \mathrm{~mm})$ was observed at after two days moisture application. In case of mean for crops the maximum shoot length $(326.0 \mathrm{~mm})$ was recorded in field pea and followed by $(201.4 \mathrm{~mm})$ in lentil whereas as the lower shoot length $(185.3 \mathrm{~mm})$ was observed in cowpea. Interaction results showed that maximum shoot length (360.0 and 340.0 $\mathrm{mm}$ ) was observed at daily and alternate day moisture application $\times$ crop field pea 
and the minimum interaction value (160.0 $\mathrm{mm}$ ) was recorded after two days moisture application $\times$ crop cow pea.

\section{Root length ( $\mathbf{m m})$}

The data for root length of pulse crops affected by different moisture stress levels, pulse crops and their interaction presented in (Table 3) was significant. The results showed that maximum root length of 112.3 and $111.9 \mathrm{~mm}$ was recorded at daily moisture and alternate day moisture application; whereas the minimum root length $(87.25 \mathrm{~mm})$ was observed at after two days moisture application. In case of mean for crops the maximum root length $(145.7 \mathrm{~mm})$ was recorded in field pea and the lower root length $(85.00$ and $85.89 \mathrm{~mm}$ ) was observed in lentil and cowpea, respectively. Interaction results showed that maximum root length (165.0 and 149.0 $\mathrm{mm}$ ) was observed at daily and alternate day moisture application $\times$ crop field pea and the minimum interaction value $(67.00$ $\mathrm{mm}$ ) was observed at after two days moisture application $\times$ crop lentil.

In the shoot length and rooth length ( $\mathrm{mm}$ ) results in this study are same as of by [20, 21] as water stress leaded to decrease in root length and shoot length. The crop cowpea is significantly affected by after two days moisture application and field pea is more moisture stress tolerant than other crops at alternate day moisture application and there is variation in case of root length that field pea showed better performance than cow pea. The response of a crop to drought fluctuates with crop species, crop growth stage, soil type, environment and season. Drought stress causes sequences of physiological, biochemical and morphological responses of crops, which finally results in low yield of green gram [22], this statement also supports our results that every pulse crop plants have different water requirements.

\section{Shoot fresh weight (mg)}

The data for shoot fresh weight of pulse crops affected by different moisture stress levels was significant for moisture stress, pulse crops and their interaction presented high-significant in (Table 4). The results showed that maximum shoot fresh weight (16500 and $15970 \mathrm{mg}$ ) was recorded at daily moisture and alternate day moisture application, respectively, whereas the minimum shoot fresh weight $(11950 \mathrm{mg})$ was observed at after two days moisture application. In case of mean for crops the maximum shoot fresh weight $(22640 \mathrm{mg})$ was recorded in cowpea and $(18650 \mathrm{mg}$ ) field pea, followed by $(15710 \mathrm{mg})$ in lentil whereas the lower shoot fresh weight (2227 $\mathrm{mg}$ ) was observed in mung bean. Interaction results showed that maximum shoot fresh weight (25400 and $24330 \mathrm{mg}$ ) was observed at daily and alternate day moisture application $\times$ crop cow pea, respectively and the minimum interaction value $(1820 \mathrm{mg})$ was observed at after two days moisture application $\times$ crop mung bean.

Table 1. Effect of moisture stress levels on seed germination $(\%)$ of different pulses

\begin{tabular}{|c|c|c|c|c|c|}
\hline \multirow{2}{*}{$\begin{array}{c}\text { Moisture } \\
\text { stress levels }\end{array}$} & \multicolumn{2}{|c|}{ Winter pulse crops } & \multicolumn{2}{c|}{ Summer pulse crops } & \multirow{2}{*}{ Mean } \\
\cline { 2 - 5 } & Field pea & Lentil & Cow pea & Mung bean & \\
\hline $\mathrm{M}_{1}$ & 94.00 & 92.00 & 87.67 & 72.00 & $86.42 \mathrm{~A}$ \\
\hline $\mathrm{M}_{2}$ & 92.00 & 90.00 & 84.00 & 74.00 & $85.00 \mathrm{~A}$ \\
\hline $\mathrm{M}_{3}$ & 76.00 & 68.00 & 62.00 & 56.00 & $65.50 \mathrm{~B}$ \\
\hline Mean & $87.33 \mathrm{~A}$ & $83.33 \mathrm{AB}$ & $77.89 \mathrm{~B}$ & $67.33 \mathrm{C}$ & \\
\hline
\end{tabular}

Where, $\mathrm{M}_{1}=$ Daily Moisture application, $\mathrm{M}_{2}=$ Alternate day moisture application and $\mathrm{M}_{3}=$ After 2 days moisture application 
Table 2. Effect of moisture stress levels on shoot length $(\mathrm{mm})$ of different pulses

\begin{tabular}{|c|c|c|c|c|c|}
\hline \multirow{2}{*}{$\begin{array}{c}\text { Moisture } \\
\text { stress levels }\end{array}$} & \multicolumn{2}{|c|}{ Winter pulse crops } & \multicolumn{2}{|c|}{ Summer pulse crops } & \multirow{2}{*}{ Mean } \\
\hline & Field pea & Lentil & Cow pea & Mung bean & \\
\hline $\mathrm{M}_{1}$ & $340.0 \mathrm{a}$ & $214.3 \mathrm{de}$ & $195.0 \mathrm{e}$ & $241.7 \mathrm{c}$ & $247.8 \mathrm{~B}$ \\
\hline $\mathrm{M}_{2}$ & $360.0 \mathrm{a}$ & $220.0 \mathrm{~d}$ & $201.0 \mathrm{de}$ & $254.0 \mathrm{c}$ & $258.8 \mathrm{~A}$ \\
\hline $\mathrm{M}_{3}$ & $278.0 \mathrm{~b}$ & $170.0 \mathrm{f}$ & $160.0 \mathrm{f}$ & $193.0 \mathrm{e}$ & $200.3 \mathrm{C}$ \\
\hline Mean & $326.0 \mathrm{~A}$ & $201.4 \quad \mathrm{C}$ & $185.3 \quad \mathrm{D}$ & $229.6 \mathrm{~B}$ & \\
\hline
\end{tabular}

Where, $\mathrm{M}_{1}=$ Daily Moisture application, $\mathrm{M}_{2}=$ Alternate day moisture application and $\mathrm{M}_{3}=$ After 2 days moisture application

Table 3. Effect of moisture stress levels on root length $(\mathrm{mm})$ of different pulses

\begin{tabular}{|c|c|c|c|c|c|}
\hline \multirow{2}{*}{$\begin{array}{c}\text { Moisture } \\
\text { stress levels }\end{array}$} & \multicolumn{2}{|c|}{ Winter pulse crops } & \multicolumn{2}{|c|}{ Summer pulse crops } & \multirow{2}{*}{ Mean } \\
\hline & Field pea & Lentil & Cow pea & Mung bean & \\
\hline $\mathbf{M}_{1}$ & $165.0 \mathrm{a}$ & 92.00 cde & $86.67 \mathrm{def}$ & $104.0 \mathrm{bcd}$ & $111.9 \mathrm{~A}$ \\
\hline $\mathbf{M}_{2}$ & $149.0 \mathrm{a}$ & 96.00 cde & $93.00 \mathrm{de}$ & $111.0 \mathrm{bc}$ & $112.3 \mathrm{~A}$ \\
\hline $\mathrm{M}_{3}$ & $123.0 \mathrm{~b}$ & $67.00 \mathrm{f}$ & 78.00 ef & 81.00 ef & $87.25 \quad \mathrm{~B}$ \\
\hline Mean & $145.7 \mathrm{~A}$ & $85.00 \mathrm{C}$ & $85.89 \mathrm{C}$ & $98.67 \quad \mathrm{~B}$ & \\
\hline
\end{tabular}

Where, $\mathrm{M}_{1}=$ Daily Moisture application, $\mathrm{M}_{2}=$ Alternate day moisture application and $\mathrm{M}_{3}=$ After 2 days moisture application

Table 4. Effect of moisture stress on shoot fresh weight (mg) of different pulses

\begin{tabular}{|c|c|c|c|c|c|}
\hline \multirow{2}{*}{$\begin{array}{c}\text { Moisture } \\
\text { stress levels }\end{array}$} & \multicolumn{2}{|c|}{ Winter pulse crops } & \multicolumn{2}{|c|}{ Summer pulse crops } & \multirow{2}{*}{ Mean } \\
\hline & Field pea & Lentil & Cow pea & Mung bean & \\
\hline $\mathrm{M}_{1}$ & $19330 \mathrm{c}$ & $16820 \mathrm{de}$ & $25400 \mathrm{a}$ & $2340 \mathrm{~g}$ & $15970 \mathrm{~A}$ \\
\hline $\mathrm{M}_{2}$ & $21250 \mathrm{~b}$ & $17900 \mathrm{~cd}$ & $24330 \mathrm{a}$ & $2520 \mathrm{~g}$ & $16500 \mathrm{~A}$ \\
\hline $\mathrm{M}_{3}$ & $15360 \mathrm{e}$ & $12420 \mathrm{f}$ & $18200 \mathrm{~b}$ & $1820 \mathrm{~g}$ & $11950 \mathrm{~B}$ \\
\hline Mean & $18650 \mathrm{~B}$ & $15710 \mathrm{C}$ & $22640 \mathrm{~A}$ & $2227 \quad \mathrm{D}$ & \\
\hline
\end{tabular}

Where, $\mathrm{M}_{1}=$ Daily Moisture application, $\mathrm{M}_{2}=$ Alternate day moisture application and $\mathrm{M}_{3}=$ After 2 days moisture application

\section{Root fresh weight (mg)}

The data for root fresh weight of pulse crops affected by different moisture stress levels was significant for moisture stress, pulse crops and their interaction presented high-significant in (Table 5). The results showed that maximum root fresh weight (13420 mg) was recorded at alternate day moisture application; whereas the minimum root fresh weight $(9173 \mathrm{mg}$ ) was observed after two days moisture application. In case of mean for crops the maximum root fresh weight $(17110 \mathrm{mg})$ was recorded in cowpea and $(14610 \mathrm{mg})$ in field pea followed by $(12300 \mathrm{mg})$ in lentil whereas the lower root fresh weight (1877 $\mathrm{mg}$ ) was observed in mung bean. Interaction results showed that maximum root fresh weight (19100 mg) was observed at alternate day moisture application $\times$ crop cow pea and the minimum interaction value (1510 mg) was observed at after two days moisture application $\times$ crop mung bean.

\section{Shoot dry weight (mg)}

The data for shoot dry weight of pulse crops affected by different moisture stress levels was significant for moisture stress, pulse crops and their interaction presented highsignificant in (Table 6). The results showed that maximum shoot dry weight (1970 and $2050 \mathrm{mg}$ ) was recorded at daily moisture and alternate daily moisture application, whereas the minimum shoot dry weight (1455 mg) was observed at after two days moisture application. In case of mean for crops the maximum shoot dry weight (2513 $\mathrm{mg}$ ) was recorded in cow pea and (2070 $\mathrm{mg}$ ) in field pea followed by (1744 $\mathrm{mg})$ in lentil whereas the lower shoot dry weight (246.7 $\mathrm{mg}$ ) was observed in mung bean. 
Interaction results showed that maximum shoot dry weight $(2834 \mathrm{mg}$ ) was observed at alternate day moisture application $\times$ crop field pea and the minimum interaction value $(200.0 \mathrm{mg})$ was observed after two days moisture application $\times$ crop mung bean.

\section{Root dry weight (mg)}

The data for root dry weight of pulse crops affected by different moisture stress levels was significant for moisture stress, pulse crops and their interaction presented highsignificant in (Table 7). The results showed that maximum root dry weight $(1430 \mathrm{mg})$ was recorded at daily moisture application, whereas the minimum root dry weight (1069 and $1105 \mathrm{mg}$ ) was observed at alternate day moisture and two days after moisture application. In case of mean for crops the maximum root dry weight (1897 $\mathrm{mg}$ ) was recorded in cow pea and (1363 $\mathrm{mg}$ ) in lentil followed by (1342 $\mathrm{mg})$ in field pea whereas as the lower root dry weight (203.6 mg) was observed in mung bean. Interaction results showed that maximum root dry weight $(2150 \mathrm{mg}$ ) was observed at daily moisture application $\times$ crop field pea and the minimum interaction value (160.0 mg) was observed at after two days moisture application $\times$ crop mung bean. Subbarao and his fallows concluded that shoot and root traits play an important role in regulating water use by crop plant. Our results showed that high moisture stress decreased the shoot fresh weight $(\mathrm{mg})$ of mung bean after two days moisture application and shoot fresh weight were observed increased in field pea at alternate day moisture application [23]. In case of root fresh weight cowpea showed optimum growth at daily moisture application whereas lentil and mung bean showed decreased in shoot fresh weight and root fresh weight. Anbessa and Bejiga [24] also found significant decreased in dry root weight, root volume and rooting depth under low moisture stress. This statement also favors results that if the shoot and root does not shows optimum growth then the plants cannot perform their physiological process as well as early growth traits. The shoot dry weight and root dry weight $(\mathrm{mg})$ were significantly affected in mung bean after two days moisture application whereas the shoot dry weight and root dry weights were found increased in cow pea at alternate day moisture application and daily moisture application, respectively.

Table 5. Effect of moisture stress levels on root fresh weight (mg) of different pulses

\begin{tabular}{|c|c|c|c|c|c|}
\hline \multirow{2}{*}{$\begin{array}{c}\text { Moisture } \\
\text { stress levels }\end{array}$} & \multicolumn{2}{|c|}{ Winter pulse crops } & \multicolumn{2}{|c|}{ Summer pulse crops } & \multirow{2}{*}{ Mean } \\
\hline & Field pea & Lentil & Cow pea & Mung bean & \\
\hline $\mathrm{M}_{1}$ & $15100 \mathrm{c}$ & $12360 \mathrm{~d}$ & $17900 \mathrm{~b}$ & $2020 \mathrm{f}$ & $11850 \mathrm{~B}$ \\
\hline $\mathrm{M}_{2}$ & $17330 \mathrm{~b}$ & $15150 \mathrm{c}$ & $19100 \mathrm{a}$ & $2100 \mathrm{f}$ & $13420 \mathrm{~A}$ \\
\hline $\mathrm{M}_{3}$ & $11450 \mathrm{~d}$ & $9400 \mathrm{e}$ & $14330 \mathrm{c}$ & $1510 \mathrm{f}$ & $9173 \mathrm{C}$ \\
\hline Mean & $14630 \mathrm{~B}$ & $12300 \mathrm{C}$ & 17110. A & $1877 \quad \mathrm{D}$ & \\
\hline
\end{tabular}

Where, $\mathrm{M}_{1}=$ Daily Moisture application, $\mathrm{M}_{2}=$ Alternate day moisture application and $\mathrm{M}_{3}=$ After 2 days moisture application

Table 6. Effect of moisture stress levels on shoot dry weight (mg) of different pulses

\begin{tabular}{|c|c|c|c|c|c|}
\hline \multirow{2}{*}{$\begin{array}{c}\text { Moisture } \\
\text { stress levels }\end{array}$} & \multicolumn{2}{|c|}{ Winter pulse crops } & \multicolumn{2}{c|}{ Summer pulse crops } & Mean \\
\cline { 2 - 6 } & Field pea & Lentil & Cow pea & Mung bean & \\
\hline $\mathrm{M}_{1}$ & $2564 \mathrm{bc}$ & $2235 \mathrm{de}$ & $2820 \mathrm{ab}$ & $260.0 \mathrm{~h}$ & $1970 \mathrm{~A}$ \\
\hline $\mathrm{M}_{2}$ & $2834 \mathrm{a}$ & $2385 \mathrm{~cd}$ & $2700 \mathrm{ac}$ & $280.0 \mathrm{~h}$ & $2050 \mathrm{~A}$ \\
\hline $\mathrm{M}_{3}$ & $1994 \mathrm{ef}$ & $1605 \mathrm{~g}$ & $2020 \mathrm{f}$ & $200.0 \mathrm{~h}$ & $1455 \mathrm{~B}$ \\
\hline Mean & $2070 \mathrm{~B}$ & $1745 \mathrm{C}$ & $2513 \mathrm{~A}$ & $246.7 \mathrm{D}$ & \\
\hline
\end{tabular}

Where, $\mathbf{M}_{1}=$ Daily Moisture application, $\mathbf{M}_{2}=$ Alternate day moisture application and $\mathbf{M}_{3}=$ After 2 days moisture application 
Table 7. Effect of moisture stress levels on root dry weight (mg) of different pulses

\begin{tabular}{|c|c|c|c|c|c|c|}
\hline \multirow{2}{*}{$\begin{array}{c}\text { Moisture stress } \\
\text { levels }\end{array}$} & \multicolumn{2}{|c|}{ Winter pulse crops } & \multicolumn{2}{c|}{ Summer pulse crops } & \multirow{2}{*}{ Mean } \\
\cline { 2 - 6 } & Field pea & Lentil & Cow pea & Mung bean & & \\
\hline $\mathrm{M}_{1}$ & $2150 \mathrm{a}$ & $1370 \mathrm{c}$ & $1980 \mathrm{a}$ & $220.7 \mathrm{e}$ & $1430 \mathrm{~A}$ \\
\hline $\mathrm{M}_{2}$ & $245.7 \mathrm{e}$ & $1680 \mathrm{~b}$ & $2120 \mathrm{a}$ & $230.0 \mathrm{e}$ & $1069 \mathrm{~B}$ \\
\hline $\mathrm{M}_{3}$ & $1630 \mathrm{~b}$ & $1040 \mathrm{c}$ & $1590 \mathrm{~b}$ & $160.0 \mathrm{e}$ & $1105 \mathrm{~B}$ \\
\hline Mean & $1342 \mathrm{~B}$ & $1363 \mathrm{~B}$ & $1897 \mathrm{~A}$ & $203.6 \quad \mathrm{C}$ & & \\
\hline
\end{tabular}

Where, $\mathbf{M}_{1}=$ Daily Moisture application, $\mathbf{M}_{2}=$ Alternate day moisture application and $\mathbf{M}_{3}=$ After 2 days moisture application

\section{Conclusion}

It is concluded from the results that daily and alternate day moisture application resulted better seed germination, establishment and development of early seedling plant growth traits and two days after moisture application showed stress as the result of poor growth of early plant traits. It is further derivated from the data in winter pulse crop field pea resulted the best seed germination and early plant growth traits than lentil while in summer pulse crops cowpea showed better performance in terms of seed germination and early establishment attributes. On the basis of these preliminary experimentation, the farming community is advised to prefer those crops in winter as well as in summer which are more resistant against moisture stress in view of diminishing water resources in the country.

\section{Authors' contributions}

Conceived and designed the experiments: $\mathrm{Z}$ Ullah \& S Ahmad, Performed the experiments: S Ahmad, Analyzed the data: Z Ullah, MR Siddiqui \& ZU Haq, Contributed materials/ analysis/ tools: $S$ Latif, Wrote the paper: Z Ullah.

\section{References}

1. Tejera NA, Soussi $M$ \& Lluch $C$ (2006). Physiological and nutritional indicators of tolerance to salinity in chickpea plants growing under symbiotic conditions. Environ Exp Bot 58:17-24.

2. Mwale SS, Hamusimbi C \& Mwansa K (2003). Germination, emergence and growth of sunflower (Helianthus annuus L.) in response to osmotic seed priming. Seed Sci Technol 31: 199206.

3. Okcu GM, Kaya D \& Atak M (2005). Effects of salt and drought stresses on germination and seedling growth of pea (Pisum sativum L.). Turk J Agric 29: 237-242.

4. Willenborb CJ, Gulden RH, Jhonson EN \& Shirtliffe SJ (2004). Germination characteristics of polymer-coat canola (Brassica napus L.) seeds subjected to moisture stress at different temperatures. Agron J 96: 786-791.

5. Wilson DR, Jamieson PD, Jermyn WA \& Hanson R (1985). Models of growth and water use of field pea (Pisum sativum L.). In: (ed. Hebblethwaite PD, Heath MC \& Dawkins TCK) the Pea Crop. Butterworths London, UK.

6. Almansouri M, Kinet JM \& Lutts L (2001). Effect of salt and osmotic stresses on germination in durum wheat (Triticum aestivum L.). Plant Soil 231: 243-254.

7. Boyer JS (1982). Plant productivity and environment. Sci 218: 443-448.

8. Hsu YT \& Kao CH (2003). Role of abscisic acid in cadmium tolerance of rice (Oryza sativa L.) seedlings. Plant Cell Environ 26: 867-874.

9. Turk MA, Rahman A, Tawaha A \& Lee DK (2004). Seedling growth of three lentil cultivars under moisture stress. Asian J Plant Sci 3(3): 394-397.

10. Taylor AG, Moles JE \& Kirkham NB (1982). Germination and seedling growth characteristics of three tomato species affected by water deficits. $J$ Americ Soci Hort 107: 282-285. 
11. Davis DW, Oelke EA, Oplinger ES, Doll JD, Hanson CV \& Putnam DH (1991). Cowpea: Alt field crops manual. www.hort. purdue. Edu / new crop / afcm / cowpea.htlm.

12. Ahmed ZU, Shaikh MAQ, Khan AI \& Kaul A (1978). Evaluation of local, exotic and mutant germplasm of mungbean for varietal characters and yield in Bangladesh. SABRAO J 10: 48.

13. Nabizade $M$, Tayeb SN \& Mani M (2011). Effect of irrigation on the yield of mungbean cultivars. J Americ Sci 7(7): 86-90.

14. Allahmoradi $P$, Ghobadi $M$ \& Taherabadi S (2011). Physiological aspects of mungbean in response to drought stress. Conf Food Eng Biotechnol Vol 9 IPCBEE press, Singapoore.

15. Srivalli B, Chinnusamy V \& Chopra RK (2003). Antioxidant defense in response to abiotic stresses in plants. $J$ Plant Biol 30: 121-139.

16. Sarke A, Erskine W \& Singh M (2003). Regression models for lentil seed and straw yields in Near East. Agric Forest Meteor 116: 61-72.

17. Gomez KA \& Gomez AA (1984). Statistics for Agricultural Research (Second Edition). John Willey and Sons, New York.

18. Zhu JK (2002). Salt and drought stress signal transduction in plants, Annual Rev Plant Biol 53: 247-273.
19. Kaya MD, Okcub G, Ataka M, Cikılıc Y \& Kolsaricia O (2006). Seed treatments to overcome salt and drought stress during germination in sunflower (Helianthus annuus L.). Eurp J Agron 24: 291-295.

20. Kaydam D, \& Yagnur M (2008). Germination, seedling growth and relative water content of shoot in different seed sizes of triticale under osmotic stress of water and $\mathrm{NaCl}$. Afric J Biotech 7(16): 2862- 2868.

21. Agnihotri RK, Palni LMS \& Pandey DK (2007). Germination and seeding growth under moisture stress. Screening of landraces of Rice (Oryza sativa L.) from Kumaun region of Indian central Himalaya. J Plant Biol 34(1): 21-27.

22. Malik A, Hassan F, Waheed A, Qadir $G$ \& Asghar R (2006). Interactive effects of irrigation and phosphorus on green gram (Vigna radiata L.). Pakistan J Bot 38(4): 1119-1126.

23. Subbarao G, Johansen VC, Slinkard AE, Rao RCN, Saxena NP \& Chuhan YS (1995). Strategies for improving drought resistance in grain legumes. Critical Rev Plant Sci 14: 469-523.

24. Anbessa Y \& Bejiga G (2002). Evaluation of Ethiopian chickpea landraces for tolerance to drought. Genetic Res Crop Evol 49(6): 557-564. 